\title{
A Basis for Relative Growth Rate Differences Between Native and Invasive Forb Seedlings
}

\author{
Jeremy J. James ${ }^{1}$ and Rebecca E. Drenousky ${ }^{2}$ \\ Authors are ${ }^{1}$ Plant Physiologist, USDA-Agricultural Research Service, Eastern Oregon Agricultural Research Center, 67826-A Hwy 205, Burns, \\ OR 97720; and ${ }^{2}$ Assistant Professor of Plant Biology, Biology Department, John Carroll University, University Heights, OH $44118-4581$.
}

\begin{abstract}
The ability of invasive plants to achieve higher relative growth rates (RGR) than their native counterparts has been widely documented. However, the mechanisms allowing invasives to achieve higher RGR are poorly understood. The objective of this study was to determine the basis for RGR differences between native and invasive forbs that have widely invaded nutrient-poor soils of the Intermountain West. Six native and 6 invasive forbs were seeded in pots in a greenhouse, and 4 harvests were conducted over a 2-month period. These 4 harvests were used to calculate RGR and the components of RGR, net assimilation rate (rate of dry matter production per unit leaf area), leaf area ratio (LAR, leaf area per unit total plant mass), leaf mass ratio (the proportion of biomass allocated to leaves), and specific leaf area (SLA, leaf area per unit leaf biomass). Mean RGR of the 12 study species ranged between 0.04 and $0.15 \mathrm{~g} \cdot \mathrm{g}^{-1} \cdot \mathrm{d}^{-1}$ but was significantly higher for invasive forbs compared to native forbs $(P=0.036)$. The higher RGR achieved by invasive forbs was due mainly to a greater SLA and LAR. This indicates that invasive forbs achieved higher RGR than natives primarily by creating more leaf area per unit leaf mass, not by allocating more biomass to leaf tissue or by having a higher net rate of dry matter production. A high degree of variation in RGR, SLA, and LAR was observed in native forbs, suggesting that the ability to design weed-resistant plant communities may be improved by managing for specific functional traits as opposed to functional groups.
\end{abstract}

\section{Resumen}

La capacidad de las plantas invasoras para lograr tasas relativas de crecimiento (RGR) superiores a sus contrapartes nativas ha sido ampliamente documentada. Sin embargo, los mecanismos que permiten a estas plantas lograr mayores RGR son poco entendidos. El objetivo de este estudio fue determinar las basas de la diferencia de la RGR entre hierbas nativas e invasoras que han invadido ampliamente suelos pobres en nutrientes de la región ínter montañosa del oeste. Seis especies herbáceas nativas y seis invasoras se sembraron en macetas en un invernadero y se cosecharon cuatro veces en un periodo de dos meses. Estas cosechas se usaron para calcular la RGR y sus componentes, la tasa de asimilación neta (la tasa de producción de materia seca por unidad de área foliar), la relación de área foliar (LAR, área foliar por unidad total de biomasa de la planta), la relación de masa foliar (la proporción de biomasa asignada a las hojas) y el área foliar específica (SLA, el área foliar por unidad de biomasa de hojas). La RGR media de las 12 especies en estudio varió de 0.04 a $0.15 \mathrm{~g} \cdot \mathrm{g}^{-1} \cdot \mathrm{d}^{-1}$, pero fue significativamente mayor en las especies invasoras que en las nativas $(P=0.036)$. La mayor RGR lograda por las hierbas invasoras se debió principalmente a su mayor SLA y LAR. Esto indica que las especies invasoras lograron una mayor RGR que las nativas al producir mas área foliar por unidad de biomasa de hojas, no por asignar más biomasa al tejido foliar o por tener una mayor tasa neta de producción de materia seca. Se observó un alto grado de variación de RGR, SLA y LAR en las hierbas nativas, sugiriendo que la capacidad para diseñar comunidades de plantas resistentes a las malezas puede ser mejorada manejando características funcionales específicas opuestas a los grupos funcionales.

Key Words: nutrients, specific leaf area, weeds, yarrow

\section{INTRODUCTION}

Relative growth rate (RGR) differences between native and invasive plant species is widely thought to be a major factor contributing to invasion, particularly following disturbance (Baker 1974; Grime and Hunt 1975). RGR is a complex parameter determined by a number of physiological, morphological and biomass-allocation components. Much research has centered on describing RGR differences between native and invasive species (Baskin et al. 1999; Bellingham et al. 2004;

Correspondence: Jeremy J. James, USDA-Agricultural Research Service, Eastern Oregon Agricultural Research Center, 67826-A Hwy 205, Burns, OR 97720. Email: jeremy.james@ oregonstate.edu

Manuscript received 2 November 2006; manuscript accepted 8 April 2007.
Burns 2004). Less is known, however, about the underlying mechanisms driving RGR differences between native and invasive species. Such understanding is critical for effective management of current invaders and prediction and management of future invaders.

Native species adapted to the nutrient-poor soils of arid and semiarid rangelands often exhibit a lower RGR than their invasive counterparts (Cronk and Fuller 1995; Pattison et al. 1998; Garcia-Serrano et al. 2005), and the magnitude of these differences often intensifies with increased resource availability (Daehler 2003). A high RGR allows invasives to rapidly occupy space and capture resources and reduces the time between vegetative growth and reproduction (Poorter 1989). The advantages of low RGR demonstrated by native species, however, are less clear, causing some researchers to suggest 
Table 1. List of the 12 species used in this study. Nomenclature follows the USDA, NRCS (2007) PLANTS database (http:// plants.usda.gov/index.html).

\begin{tabular}{|c|c|c|c|}
\hline & Common name & Species & $\begin{array}{c}\text { Species } \\
\text { abbreviation }\end{array}$ \\
\hline \multicolumn{4}{|l|}{ Native forbs } \\
\hline & Common yarrow & $\begin{array}{l}\text { Achillea millefolium L. var. } \\
\text { occidentalis DC. }\end{array}$ & (ACMI) \\
\hline & $\begin{array}{l}\text { Common woolly } \\
\text { sunflower }\end{array}$ & $\begin{array}{l}\text { Eriophyllum lanatum } \\
\text { (Pursh) Forbes }\end{array}$ & (ERLA) \\
\hline & $\begin{array}{l}\text { Rocky mountain } \\
\text { penstemon }\end{array}$ & Penstemon strictus Benth. & (PEST) \\
\hline & Western hawksbeard & Crepis occidentalis Nutt. & (CROC) \\
\hline & Lewis flax & Linum lewisii Pursh & (LILE) \\
\hline & Munro globemallow & $\begin{array}{l}\text { Sphaeralcea munroana } \\
\text { (Dougl. ex Lindl.) }\end{array}$ & (SPMU) \\
\hline \multicolumn{4}{|l|}{ Invasive forbs } \\
\hline & Spotted knapweed & Centaurea stoebe L. & (CEST) \\
\hline & Rush skeletonweed & Chondrilla juncea L. & (CHJU) \\
\hline & Dalmatian toadflax & $\begin{array}{l}\text { Linaria dalmatica (L.) P. } \\
\text { Mill. }\end{array}$ & (LIDA) \\
\hline & Whitetop & Cardaria draba (L.) Desv. & (CADR) \\
\hline & Common teasel & Dipsacus fullonum L. & (DIFU) \\
\hline & Scotch thistle & Onopordum acanthium L. & (ONAC) \\
\hline
\end{tabular}

that natural selection in nutrient-poor environments has targeted one of the underlying components of RGR instead of RGR itself (Lambers and Dijkstra 1987). For example, traits allowing conservation and efficient use of resources may be advantageous in resource-poor systems, but these traits also may lower RGR. In turn, these traits may not be advantageous following disturbance when resource availability increases.

Plant growth analysis decomposes RGR into net assimilation rate (NAR, rate of dry matter production per unit leaf area) and leaf area ratio (LAR, leaf area per unit total plant mass), where RGR $=$ NAR $\times$ LAR (Evans 1972; Causton and Venus 1981) NAR is determined primarily by the ratio of carbon gained through photosynthesis and carbon lost through respiration. LAR reflects the amount of leaf area a plant develops per unit total plant mass and, therefore, depends on the proportion of biomass allocated to leaves relative to total plant mass (leaf mass ratio, LMR) and how much leaf area a plant develops perunit leaf biomass (specific leaf area, SLA), where $\mathrm{LAR}=\mathrm{LMR} \times$ SLA

Most work evaluating RGR variation among species has compared species from habitats differing in fertility or productivity. Early studies demonstrated that the higher RGR achieved by species from fertile habitats was a result of differences in LAR and SLA between species (Poorter and Remkes 1990). Later experiments and recent meta-analysis attribute these differences to variation in NAR, not LAR or SLA (Villar et al. 2005; Shipley 2006). Other studies have found that both NAR and SLA contribute significantly to differences in RGR among species (Grotkopp et al. 2002). These variable results suggest that a number of mechanisms could drive RGR differences between native and invasive species. Invasives could achieve higher RGR than natives by having higher rates of photosynthesis and/or lower rates of respiration (high NAR), allocating more biomass to leaves (high LMR), or producing thinner or less dense leaves resulting in more leaf area per unit leaf biomass (high SLA).

Only a few studies have evaluated the underlying causes of RGR variation between native and invasive species. In the Great Basin, invasive annual grasses generally have greater LAR and SLA but not NAR than bunchgrasses (Arredondo et al. 1998). However, annual grasses, in general, tend to have lower LAR and SLA than perennials, so it is not necessarily clear that these traits were unique to invaders in this system (Garnier 1992). In a comparison of invasive and noninvasive Pinus species, differences in NAR, LMR, and SLA all contributed to variation in RGR, but SLA was the main factor allowing invasives to achieve a higher RGR than noninvasive pines (Grotkopp et al. 2002). Together, these studies suggest SLA may be a key factor driving RGR differences between native and invasive plants. In support, high SLA has been correlated to invasion success at both the community and the continental scale (Lake and Leishman 2004; Hamilton et al. 2005). Producing more leaf area per unit biomass may provide a greater overall return on carbon investment, allowing invasive plants to achieve higher RGR than natives.

The objective of this study was to determine the mechanistic basis for RGR differences between native and invasive forbs that are widely established on the nutrient-poor soils of the Intermountain West. Path analysis was used to identify the physiological and morphological components of RGR that drive RGR differences between native and invasive species. We predicted that greater SLA would be the key factor allowing invasives to achieve a higher RGR than natives.

\section{METHODS}

\section{Study Species, Growth Conditions, and Harvests}

We selected 6 perennial native forbs and 6 perennial invasive forbs for the experiment (Table 1). The pool of native forbs consisted of species locally abundant to eastern Oregon and species used widely in restoration efforts in the Intermountain West. The pool of invasive forbs consisted of species that have extensively invaded areas of the Intermountain West as well as other ecosystems in North America. The study was conducted in spring 2006 in a greenhouse at the Eastern Oregon Agricultural Research Center (Burns, OR). The greenhouse was covered with shade cloth to minimize excessive heating. Air temperatures during the study averaged $18^{\circ} \mathrm{C}$ with a low and high daily mean of $8^{\circ} \mathrm{C}$ and $29^{\circ} \mathrm{C}$. Photosynthetically active radiation on sunny days in the greenhouse at solar noon ranged between 700 and $800 \mu \mathrm{mol} \cdot \mathrm{m}^{-2} \cdot \mathrm{s}^{-1}$.

Seeds of each species were collected from the field or purchased. Approximately 10-20 seeds of a species were planted in pots filled with a 1:1 mixture of sandy loam field soil and coarse sand. For each species, 10 pots were seeded for each of 4 harvests for a total of 40 pots per species and 480 pots in the experiment $(12$ species $\times 4$ harvests $\times 10$ replicates $=480$ ). Pots of each species were arranged in a completely randomized design. Pot sizes for the first and second harvest were $4 \mathrm{~cm}$ in diameter by $21 \mathrm{~cm}$ deep and $12 \mathrm{~cm}$ in diameter by $36 \mathrm{~cm}$ deep, respectively. Larger pots $(20 \mathrm{~cm}$ diameter by 
$50 \mathrm{~cm}$ deep) were used for the third and fourth harvests. Pots were checked daily for seedling emergence. One week after the first seedling emerged, seedlings were thinned to a common size, leaving 1 seedling per pot. The first harvest was conducted 1 week after the cotyledons had fully emerged and the first true leaves were observed. The second, third, and fourth harvests were conducted at 2-week intervals after the first harvest. A preliminary study demonstrated that smaller pot sizes did not alter seedling growth compared to larger pots during the first 3 weeks of seedling growth. During the experiment, seedlings were supplied with ample water and nutrients by saturating pots 4 times a week with $2 \mathrm{~L}$ of one-quarter-strength modified Hoagland's solution to achieve a moisture content close to 20\% (Epstein 1972). At each harvest, aboveground biomass was clipped and separated into leaves and stems, and roots were washed over a fine-mesh screen. Leaf and root samples were then scanned for area and length (WinRHIZO, Regent Instruments Inc., Saint-Foy, Canada), respectively, then dried at $65^{\circ} \mathrm{C}$ and weighed. Root mass ratio was quantified as the proportion of total plant biomass allocated to roots.

\section{Growth Analysis and Statistics}

RGR, NAR, LAR, SLA, LMR, and relative root elongation rate (RRER; based on changes in root length) were calculated over all harvest intervals. Calculations of means, standard errors, and $95 \%$ confidence intervals followed Causton and Venus (1981) for ungraded and unpaired harvests. A completely randomized analysis of variance (ANOVA) model was used to analyze how patterns of RGR and the components of RGR differed between native and invasive forbs (SAS Institute 2001). Assumptions of ANOVA were evaluated using the ShapiroWilk's test for normality and Levene's test for homogeneity of variance. When these assumptions were violated, data were weighted by the inverse of the variance (Neter et al. 1990). Linear and quadratic contrasts were used to test how RGR patterns changed over time.

Table 2. Relative growth rate (RGR) of invasive and native forbs over 3 harvest intervals (mean $\pm \mathrm{SE}, n=10$ ). The first harvest was conducted 1 week after cotyledon emergence. Three more harvests were conducted at 2-week intervals. Means and standard errors represent the midpoint of a harvest interval. Species abbreviations follow Table 1.

\begin{tabular}{|c|c|c|c|c|}
\hline & \multirow[b]{2}{*}{ Species } & \multicolumn{3}{|c|}{ Days after cotyledon emergence } \\
\hline & & 14 & 28 & 42 \\
\hline \multirow[t]{6}{*}{ Invasive } & DIFU & $0.126(0.05)$ & $0.130(0.01)$ & $0.149(0.02)$ \\
\hline & LIDA & $0.104(0.02)$ & $0.131(0.01)$ & $0.152(0.01)$ \\
\hline & CEST & $0.093(0.03)$ & $0.136(0.01)$ & $0.113(0.01)$ \\
\hline & CHJU & $0.118(0.07)$ & $0.174(0.04)$ & $0.133(0.02)$ \\
\hline & ONAC & $0.101(0.04)$ & $0.146(0.02)$ & $0.132(0.01)$ \\
\hline & CADR & $0.141(0.03)$ & $0.162(0.01)$ & $0.127(0.01)$ \\
\hline \multirow[t]{6}{*}{ Native } & SPMU & $0.125(0.04)$ & $0.149(0.02)$ & $0.142(0.01)$ \\
\hline & ACMI & $0.143(0.03)$ & $0.147(0.01)$ & $0.138(0.01)$ \\
\hline & ERLA & $0.061(0.04)$ & $0.121(0.02)$ & $0.103(0.01)$ \\
\hline & PEST & $0.023(0.01)$ & $0.127(0.02)$ & $0.097(0.01)$ \\
\hline & LILE & $0.067(0.02)$ & $0.165(0.01)$ & $0.070(0.01)$ \\
\hline & CROC & $0.082(0.02)$ & $0.063(0.02)$ & $0.042(0.01)$ \\
\hline
\end{tabular}

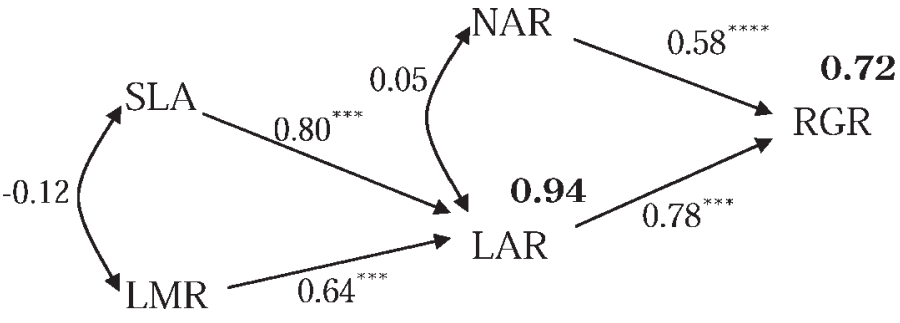

Figure 1. Path model describing how variation in net assimilation rate (NAR), leaf area ratio (LAR), specific leaf area (SLA), and leaf mass ratio (LMR) influences variation in relative growth rate (RGR) of native and invasive forbs. For each path effect the standardized partial regression coefficient is given and the significance of the path is indicated as ${ }^{\star * *} P<0.0001$. Numbers in bold are the total variance explained $\left(r^{2}\right)$ for each dependent variable. Measurements were quantified across 4 harvests spaced in 2-week intervals.

We used path analysis and structural equation modeling to determine how NAR, LAR, SLA, and LMR influence RGR of native and invasive forbs. Path analysis allows partitioning of the simple correlations among a set of variables specified in the path model. This approach allowed quantification of the degree to which each component contributed to variation in RGR and allowed determination of the basis for RGR differences between native and invasive forbs. The path coefficients in the model quantify the strength of the relationship between model variables and correspond to standardized partial regression coefficients. Path coefficients, their significance level, and the fit of the structural model to the data were evaluated using structural equation modeling with the CALIS procedure in SAS. Model fit was evaluated with the Goodness of Fit Index (GFI), which compares the predicted covariance matrix based on the specified model with the observed covariance structure from our data.

\section{RESULTS}

\section{Path Analysis}

Path analysis was used to identify the basis of RGR variation observed in the 12 study species across the 6 harvest intervals. An individual harvest could be used to calculate multiple harvest intervals (e.g., harvest 1 vs. harvest 2 and harvest 1 vs. harvest 4). The model fit index, GFI, was 0.86 , indicating a reasonable fit of our path model to the data. The variables included in the model explained $72 \%$ of the variation in RGR (Fig. 1). While NAR and LAR had strong and significant paths to RGR, a greater proportion of the variance in RGR was attributed to variation in LAR compared to NAR. Both SLA and LMR had strong and significant paths to LAR and accounted for $94 \%$ of the variation in LAR. A greater proportion of the variance in LAR was attributed to variation in SLA compared to LMR. The indirect path coefficients of LMR and SLA to RGR were 0.50 and 0.63 , respectively.

\section{Differences in RGR and RGR Components Between Native and Invasive Forbs}

Relative growth rate of invasive and native forbs generally reached a maximum between 21 and 35 days after cotyledon 


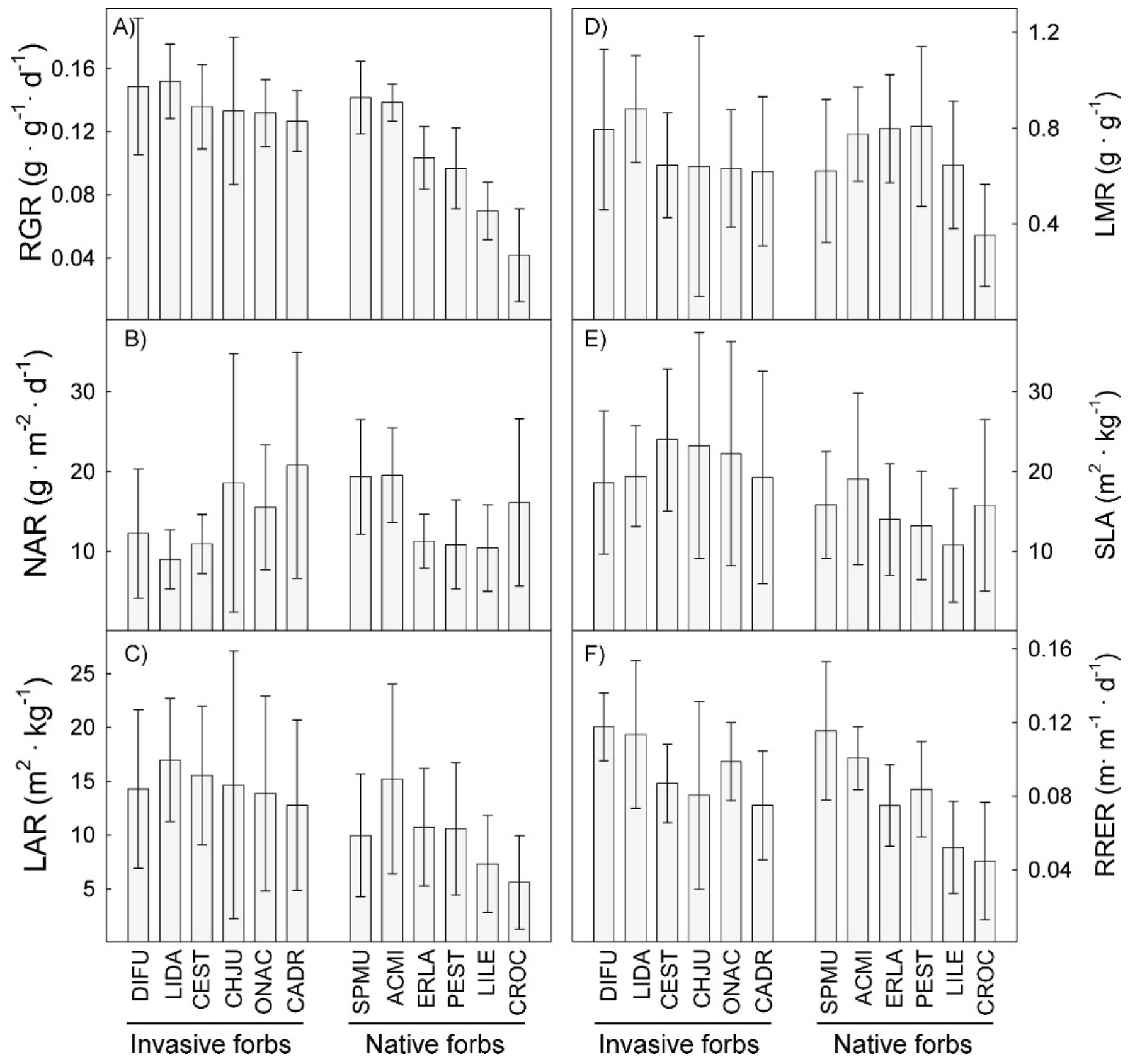

Figure 2. Mean values and $95 \%$ confidence intervals of (A) relative growth rate (RGR), (B) net assimilation rate (NAR), (C) leaf area ratio (LAR), (D) leaf mass ratio (LMR), (E) specific leaf area (SLA), and (F) relative root elongation rate (RRER) of invasive and native forbs $(n=10)$. Parameters were calculated on the basis of values from the initial and final harvest. Species abbreviations follow Table 1.

emergence (Table 2) before leveling off and/or slightly declining during subsequent harvest intervals $(P=0.016$ and $P=0.081$ for a quadratic effect of harvest time on RGR of invasive and native forbs, respectively). Averaged across all harvests, invasive forbs had greater RGR $(P=0.036)$, LAR $(P=0.008)$, and SLA $(P=0.001)$ than native forbs (Figs. 2A, $2 \mathrm{C}$, and $2 \mathrm{E})$. Invasive forbs on average had a lower root mass ratio than native forbs $(0.27 \pm 0.01,0.35 \pm 0.01$, mean \pm SE, $P<0.001)$. Invasive forbs did not differ significantly from native forbs in NAR $(P=0.972)$, LMR $(P=0.678)$, or RRER $(P=0.233) \quad$ (Figs. $2 \mathrm{~B}, 2 \mathrm{D}$, and $2 \mathrm{~F})$. There was, however, significant variation in RGR and RGR components among species within a group. As a result, not all individual pairs of native and invasive species differed significantly in RGR and RGR components. For example, RGR of native forbs ranged between 0.04 and $0.14 \mathrm{~g} \cdot \mathrm{g}^{-1} \cdot \mathrm{d}^{-1}$, and at least 2 native species, Achillea millefolium and Sphaeralcea munroana, demonstrated growth rates comparable to invasive forbs.

\section{DISCUSSION}

\section{Determinants of RGR Variation Among Forbs}

Variation in RGR among the 12 study species was due to variation in leaf area produced per unit total plant mass (LAR) and the rate of dry matter production per unit leaf area (NAR) 
(Fig. 1). This contrasts with previous work examining RGR variation among herbaceous species from habitats differing in soil fertility or productivity in which higher RGR was conferred by greater LAR, not NAR (Konings 1989; Poorter and Remkes 1990; Poorter and Pothmann 1992). This discrepancy may be related to the degree of correlation between NAR and LAR in the different experiments. In previous studies, a strong negative correlation between NAR and LAR has been observed. If LAR has a strong positive effect on RGR, then a negative correlation between NAR and LAR will result in a negative correlation between NAR and RGR (Poorter 1989; Poorter and Remkes 1990). A negative correlation between LAR and NAR can occur if a higher NAR is achieved by greater investment in photosynthetic machinery, which decreases SLA and thus decreases LAR (Konings 1989). In our experiment, NAR and LAR were uncorrelated, and both influenced RGR, indicating that the higher NAR achieved by forbs with high RGR did not necessarily occur at the expense of producing more leaf area per unit leaf mass (SLA).

Variation in LAR among the 12 study species was influenced by both SLA and LMR, although variation in SLA explained more of the variation in LAR than LMR (Fig. 1). Previous studies have shown that SLA influences RGR variation of herbaceous species, but not all studies have demonstrated a role for both LMR and SLA influencing RGR (Poorter and Remkes 1990; Atkin et al. 1996). The observed positive effect of LMR on RGR, however, is in general agreement with previous work showing that fast-growing eudicots invest relatively more biomass in leaves and less in stems and roots than slowgrowing eudicots (Lambers et al. 1998).

\section{Basis for RGR Variation Between Native and Invasive Forbs}

While all the components of RGR significantly contributed to RGR variation among the study species, the higher RGR achieved by invasive forbs compared to native forbs was due mainly to a greater SLA and LAR (Figs. 2A, 2C, and 2E). Since LMR did not differ significantly between native and invasive forbs, the difference in LAR was achieved exclusively through differences in SLA. This indicates that native and invasive forbs allocate a relatively similar portion of their biomass to leaves but that invasive forbs produce more leaf area per unit biomass. Net assimilation rate did not differ between native and invasive forbs (Fig. 2B). The low SLA and high RMR of natives compared to invasives indicates that natives have less leaf area available for photosynthetic carbon gain per unit of leaf biomass and higher respiratory carbon loss. These differences in carbon economy, however, were apparently not a major factor driving differences in RGR between native and invasive forbs. Similar to our results, differences in RGR between invasive and noninvasive pines and invasive annual grasses and native perennial grasses have been linked to differences in SLA, not LMR or NAR (Arredondo et al. 1998; Grotkopp et al. 2002).

Our results and previous studies suggest that a higher SLA may be a key factor allowing invasives to achieve a higher RGR than their native counterparts. Differences in SLA between natives and invasives may be due to differences in leaf thickness or leaf tissue composition. For example, leaf tissue density will be greater in leaves with more lignin, phenolics, or other secondary compounds, resulting in lower SLA (Lambers et al. 1998). Although investment in these compounds lower SLA, they may increase leaf strength and leaf life span, improving the ability of a species to cope with herbivory and harsh environmental conditions. Therefore, differences in SLA between native and invasive forbs observed in our study may reflect alternative strategies for maintaining adequate resource levels under different environmental conditions. When resources are limiting, minimizing loss of previously captured resources may be as important in maintaining resource levels as the capture of new resources (Berendse and Aerts 1987). Under these conditions, maximizing leaf longevity by protecting leaf tissue from damage may be favored. In contrast, when resource availability is relatively high following disturbance, high leaf longevity may not be critical. Instead, greater resource capture may be realized by production of thin, short-lived leaves with low construction costs (Poorter and Remkes 1990). These alternative strategies for procuring and utilizing resources suggest that maintaining low nutrient availability may be one strategy to favor the competitive ability of natives over invasives. This study, however, assessed RGR only under high nutrient availability, and additional research is needed to evaluate how RGR differences between natives and invasives change under low nutrient conditions and with interacting neighbor plants.

\section{MANAGEMENT IMPLICATIONS}

Establishing and maintaining weed-resistant plant communities is a central goal of restoration ecologists and land managers (Sheley and Krueger-Mangold 2003). This study suggests that the ability to design weed-resistant plant communities could be improved by managing plant communities for specific functional traits instead of functional groups. For example, to minimize invasion following disturbance, it might be important to establish native species with traits such as high RGR and high root elongation rates. Based on conventional functional classification schemes (e.g., forb, grass, or shrub), we would expect that these traits would be similar among native forbs and, as a result, that different species of native forbs would have a comparable ability to inhibit establishment of invasive forbs. In our study, however, RGR and root elongation rates varied over 3.5- and 2.5-fold among native forbs, respectively. While invasive forbs as a group achieved higher RGR than native forbs, some native species, such as A. millefolium and $S$. munroana, achieved RGR and root elongation rates comparable to invasive forbs. Other native forbs, such as Crepis occidentalis and Linum lewisii, had RGR and root elongation rates that were much lower than the invasive species. Managing for desired traits as opposed to functional groups provides a mechanistic link between plant community composition and ecosystem processes and may improve the ability to design weed-resistant plant communities.

While some traits, such as phenology and rooting depth, may be relatively easy to measure, a clear drawback of a trait-based management approach is that some traits, such as RGR and resource acquisition rates, are difficult to quantify. In this study, we demonstrated that LAR and SLA were the major factors allowing invasive forbs to achieve higher RGR than native forbs. LAR and SLA are relatively quick and easy to 
measure compared to RGR or resource acquisition rates. While LAR and SLA can be modified by environmental factors, the rankings of species SLA and LAR generally remain similar under field and laboratory conditions (Poorter and De Jong 1999). This suggests that LAR or SLA may be a useful indicator of the ability of seeded species to occupy space and sequester resources following a disturbance.

\section{LITERATURE CITED}

Arredondo, J. T., T. A. Jones, And D. A. Johnson. 1998. Seedling growth of intermountain perennial and weedy annual grasses. Journal of Range Management 51:584-589.

AtKIN, O. K., B. Botman, and H. Lambers. 1996. The causes of inherently slow growth in alpine plants: an analysis based on the underlying carbon economies of alpine and lowland Poa species. Functional Ecology 10:698-707.

BAKER, H. G. 1974. The evolution of weeds. Annual Review of Ecology and Systematics 5:1-24.

Baskin, J. M., X. Y. Nan, And C. C. Baskin. 1999. A comparative study of the seedling-juvenile and flowering stages of the life cycle in an annual and a perennial species of Senna (Leguminosae: Caesalpinioideae). American Midland Naturalist 141:381-390.

Bellingham, P. J., R. P. Duncan, W. G. Lee, and R. P. Buxton. 2004. Seedling growth rate and survival do not predict invasiveness in naturalized woody plants in New Zealand. Oikos 106:308-316.

BeRENDSE, F., AND R. AERTS. 1987. Nitrogen-use-efficiency: a biologically meaningful definition? Functional Ecology 1:293-296.

BuRNS, J. H. 2004. A comparison of invasive and non-invasive dayflowers (Commelinaceae) across experimental nutrient and water gradients. Diversity and Distributions 10:387-397.

Causton, D. R., and J. C. Venus. 1981. The biometry of plant growth. London, United Kingdom: Edward Arnold. 320 p.

Cronk, Q. B. C., and J. L. Fuller. 1995. Plant invaders. New York, NY: Chapman and Hall. 255 p.

Daehler, C. C. 2003. Performance comparisons of co-occuring native and alien invasive plants: implications for conservation and restoration. Annual Review of Ecology and Systematics 34:183-211.

EPSTEIn, E. 1972. Mineral nutrition of plants: Principles and perspectives. New York, NY: John Wiley and Sons. $412 \mathrm{p}$.

Evans, G. C. 1972. The quantitative analysis of plant growth. Berkeley: University of California Press. $761 \mathrm{p}$.

Garcia-Serrano, H., J. Escarre, E. Garmier, and X. F. Sans. 2005. A comparative growth analysis between alien invader and native Senecio species with distinct distribution ranges. Ecoscience 12:35-43.

Garnier, E. 1992. Growth analysis of congeneric annual and perennial grass species. Journal of Ecology 80:665-675.

GrIME, J. P., And R. Hunt. 1975. Relative growth-rate: its range and adaptive significance in a local flora. Journal of Ecology 63:393-422.
Grotkopp, E., M. Rejmanek, and T. L. Rost. 2002. Toward a causal explanation of plant invasiveness: seedling growth and life-history strategies of 29 pine (Pinus) species. American Naturalist 159:396-419.

Hamilton, M. A., B. R. Murray, M. W. Cadotte, G. C. Hose, A. C. Baker, C. J. Harris, AND D. LICARI. 2005. Life-history correlates of plant invasiveness at regional and continental scales. Ecology Letters 8:1066-1074.

KonIngs, H. 1989. Physiological and morphological differences between pants with a high NAR or a high LAR as related to environmental conditions. In: $\mathrm{H}$. Lambers [ED.]. Causes and consequences of variation in growth rate and productivity of higher plants. The Hague, Netherlands: SPB Academic Publishing. p. 101-123.

LAKE, J. C., AND M. R. LeISHMAn. 2004. Invasion success of exotic plants in natural ecosystems: the role of disturbance, plant attributes and freedom from herbivores. Biological Conservation 117:215-226.

Lambers, H., F. S. Chapin, and T. L. Pons. 1998. Plant physiological ecology. New York, NY: Springer-Verlag. $540 \mathrm{p}$.

LAMBERS, H., AND P. DIJKSTRA. 1987. A physiological analysis in genotypic variation in relative growth rate: can growth rate confer ecological advantage? In: J. van Andel, J. P. Bakker, and R. W. Snaydon [EDS.]. Disturbance in grasslands. Dordrecht, Netherlands: Junl. p. 237-252.

Neter, J., W. Wasserman, and M. H. Kutner. 1990. Applied linear statistical models: Regression, analysis of variance and experimental design. 3rd ed. Homewood, IL: Irwin. 1408 p.

Pattison, R. R., G. Goldstein, and A. Ares. 1998. Growth, biomass allocation and photosynthesis of invasive and native Hawaiian rainforest species. Oecologia 117:449-459.

POORTER, H. 1989. Interspecific variation in relative growth rate: on ecological causes and physiological consequences. In: H. Lambers [ED.]. Causes and consequences of variation in growth rate and productivity of higher plants. The Hague, Netherlands: SPB Academic Publishing. p. 45-68.

Poorter, H., and R. De Jong. 1999. A comparison of specific leaf area, chemical composition and leaf construction costs of field plants from 15 habitats differing in productivity. New Phytologist 143:163-176.

Poorter, H., And P. Pothmann. 1992. Growth and carbon economy of a fast-growing and a slow-growing grass species as dependent on ontogeny. New Phytologist 120:159-166.

Poorter, H., AND C. Remkes. 1990. Leaf area ratio and net assimilation rate of 24 wild species differing in relative growth rate. Oecologia 83:553-559.

SAS Institute. 2001. SAS/STAT user's guide. Version 8. Vols. 1-3. Cary, NC: SAS Institute. $1028 \mathrm{p}$.

Sheley, R. L., and J. Krueger-Mangold. 2003. Principles for restoring invasive plantinfested rangeland. Weed Science 51:260-265.

SHIPLEY, B. 2006. Net assimilation rate, specific leaf area and leaf mass ratio: which is most closely correlated with relative growth rate? A meta-analysis. Functional Ecology 20:565-574.

[USDA, nRCS] United States Department of Agriculture, Natural Resources Conservation Service. 2007. The PLANTS database. Available at: http:// plants.usda.gov. Accessed 2 April 2006.

Villar, R., F. Arenas, H. Lambers, P. Panadero, T. Maranon, and J. L. Quero. 2005. Variation in relative growth rate of 20 Aegilops species (Poaceae) in the field: the importance of net assimilation rate or specific leaf area depends on the time scale. Plant and Soil 272:11-27. 